\title{
MODEL LATIHAN KETERAMPILAN BLOCK BOLAVOLI UNTUK SISWA SEKOLAH MENENGAH KEJURUAN
}

\author{
Rusmiyadi \\ Sekolah Tinggi Keguruan Dan Ilmu Pendidikan Syekh Manshur \\ Email: yadirusmi2@gmail.com
}

\begin{abstract}
Abstrak
Penelitian ini bertujuan untuk mengembangkan model latihan keterampilan block bolavoli untuk Siswa Sekolah Menengah Kejuruan. Penelitian ini menggunakan metode penelitian pengembangan atau Research and Development $(\mathrm{RnD})$ dengan model model Borg and Gall yang terdiri dari sepuluh langkah. Jumlah siswa yang dilibatkan dalam penelitian ini yaitu berjumlah 20 siswa. Adapun instrumen yang digunakan dalan penelitian ini adalah tes. Hasil uji efektivitas nilai rata-rata hasil latihan keterampilan block bolavoli untuk Siswa Sekolah Menengah Kejuruan dalam eksperimen (menggunakan model latihan keterampilan block bolavoli) tes awal (preetest) adalah 11.20 sedangkan nilai rata-rata hasil latihan keterampilan block bolavoli dalam tes posttest sebesar 14.20 artinya terdapat perbedaan sebesar $16 \%$ dan nilai rata-rata posttest lebih tinggi dari nilai rata-rata preetest. Adapun uji signifikan perbedan dengan SPSS 20 didapat hasil t-hitung $=41.352 \mathrm{df}=19$ dan $\mathrm{p}$-value $=0.00<0.05$ yang berarti terdapat perbedaan yang sangat signifikan.
\end{abstract}

Kata Kunci: Model, Block, Latihan, Pengembangan

Abstract

This study aims to develop a training model for volleyball block skills for Vocational High School Students. This study uses a research and development (RnD) method with a model of Borg and Gall which consists of ten steps. The number of students involved in this study was 20 students. The instruments used in this study are tests. The effectiveness of the results of the average score of the training results of block volleyball skills for Vocational High School Students in the experiment (using the volleyball block skill training model) preetest is 11,20 while the average score of the volleyball block skill training in the posttest test is 14.20 , meaning that there is a difference of $16 \%$ and the positest average value is higher than the preetest average value. The significant test of difference with SPSS 20 obtained results of $t$-count $=41,352 \mathrm{df}=19$ and $p$-value $=0.00$ $<0.05$ which means that there is a very significant difference.

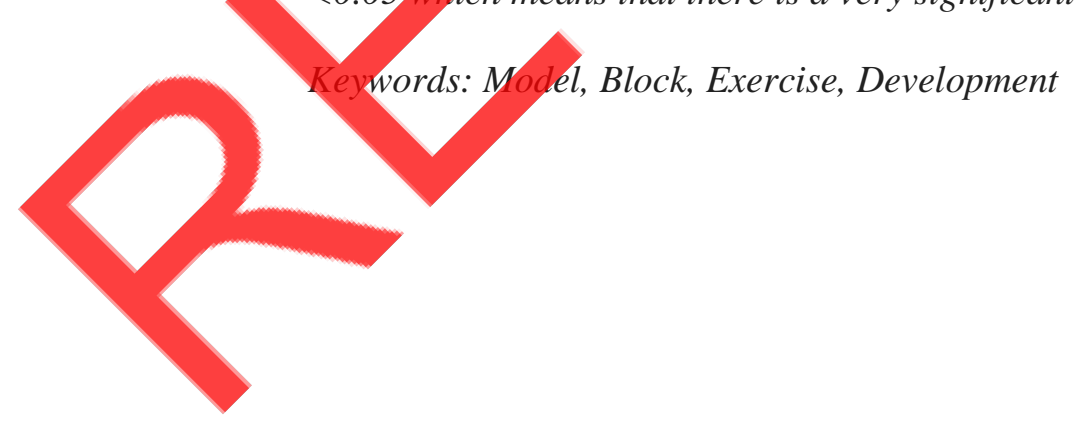




\section{PENDAHULUAN}

Permainan bolavoli menjadi salah satu olahraga yang berkembang dengan baik di masyarakat Indonesia yang meliputi semua kalangan dan usia. Dengan biaya lebih ekonomis dan lapangan yang bisa disesuaikan menjadikan bolavoli menjadi salah satu opsi yang diambil oleh masyarakat sebagai wahana penyalur hobi atau berlatih untuk meraih prestasi yang maksimal. Pembinaan dan pengembangan olahraga merupakan sebuah fondasi dalam mencapai prestasi dengan menggunakan strategi yang jitu untuk sebuah prestasi yang dibangun.

Pembinaan dan pengembangan olahraga membutuhkan prencanaan dan pola yang terprogram secara baik untuk menyelesaikan proses tiap tahapan guna mencapai prestasi hingga kepuncaknya sesuai dengan harapan. Menurut (Widowati, 2015) "pembinaan olahraga merupakan sesuatu yang tidak bisa berdiri sendiri". Untuk menjalankan suatu program pembinaan harus didukung dengan : pemain, pelatih dan orang tua yang sepakat tentang program pembinaan yang dijalankan oleh pelatih. Pembinaan dan pengembangan olahraga prestasi dilaksanakan dengan melibatkan olahragawan muda berpotensi dan hasil pemantatuan, pemanduan dan pengembangan bakat sebagai salah satu cara melakukan regenerasi.

Hal ini sangat berguna untuk mendapatkan pemain yang memiliki bakat dan kemampuan serta mengembangkan dan melestarikan agar tidak terjadi pengurangan atau krisis pemain lokal yang berprestasi. Atas dasar ini pembinaan cabang olahraga terbentuk dari berbagai usia dan instansi, yang sesuai dengan pengelompokan umur dan level, juga termasuk dalam ranah pendidikan yakni pada kegiatan ekstrakurikuler. Kemenangan merupakan suatu hal yang sangat diharapkan dalam sebuah pertandingan. Bukan hal yang mudah untuk meraih kemenangan, tersebut bisa diraih apabila pemain memiliki kemampuan individu yang baik dan memiliki kerjasama yang solid antara rekan atau tim. Kepercayaan terhadap rekan merupakan hal yâng mendasar dalam permainan tim. Tanpa adany kerjasama tim akan sangat sulit untuk meraih kemenangan.

Perkembangan bolavoli dari segi teknik tidak begitu besar, namun perubahan yang sangat signifikan erdapat pada teknik dan strategi dalam permaina baik itu dalam pola menyerang dán pola bertahan. Menurut (Achmad, 2016) "tanpa penguasaan teknik yang baik seorang pemaix tidak akan dapat mencapai prestasi yang maksimal". Hal ini berkembang sede mikian rupa yang berguna untuk meraih poin secara maksimal dan memenangkan pertandingan. Untuk mendapatkan hasil tersebut pemain harus mengoptimalkan kemampuan dalam satu pertandingan.

Menyusun pola pada saat menyerangan dan membentuk pertahanan secara terstruktur dan bervariasi memegang peranan penting dalam jalannya pertandingan. Serangan dianggap memiliki andil yang sangat besar untuk mendapatkan poin dalam pertandingan. Namun untuk membentuk pola serangan terlebih dahulu pemain harus mampu bertahan dengan baik dari serangan awal (servis) dari lawan. Dapat digaris bawahi dalam permainan bolavoli pertahanan sangat 
menentukan tingkat keberhasilan tim untuk menyusun serangan demi meraih poin.

Meraih poin dalam permainan bolavoli bukan hanya dengan menyerang, dengan bertahan pun pemain bisa mendapatkan poin. "Regu yang dapat mempertahankan diri dengan baik, seringkali bisa mengalahkan regu yang dapat menyerang dengan baik" (Beutelsthal, 2015). Apabila dilihat dari segi zona bertahan dibagi menjadi 2 bagian, yakni zona bertahan dan zona serang. Pada zona bertahan pola yang dilakukan penempatan posisi pemain terhadap serangan lawan yang pada umumnya pemain ini bertahan dengan teknik passing bawah. Sedangkan pada zona serang pola bertahan yang dilakukan dengan cara bendungan (block), teknik ini membendungi spike dari pemain lawan.

Bendungan merupakan salah satu cara bertahan yang paling efektif untuk mencuri poin dari lawan karena disaat pemain berhasil melakukan dengan baik maka bola akan jatuh di area lawan, secara otomatis itu akan menambah poin bagi regu yang melakukan bendungan (block). Block yang baik akan semakin memperkecil regu kehilangan poin yang disebabkan oleh spike dari lawan seperti keselahan menerima atau kehilangan posisi. "Block merupakan benteng pertahanan yang utama untuk menangkis serangan lawan" (Yusmar, 2017).

Keberhasilan pemain dalam melakukan block akan memberikan pengaruh yang sangat besar terhadap jalannya pertandingan karena ini bisa meningkatkan semangat regu dan memberikan presure terhadap pemain lawan. Semakin sering pemain berhasil melakukan block maka tekanan psikologis yang diterima oleh pemain lawan akan semakin bertambah, secara otomatis pemain lawan akan sulit berkonsentrasi dan hal tersebut akan mengacaukan pola permainan yang akan dibentuk.

Pertahanan yang memberikan dampak yang signifikan terhadap perkembangan pola permainan, akan tetapi hal ini tida bisa dilakukan begitu saja. Diperlukan latihan yang intensif dan berkelanjutan untuk mendapatkan hasil yang maksimal. Pengalama dalam bermain juga menjadi modal yang kuat dalam melaksanakannya.

Pemain profesional hal ini bukanlah sesuatu yang sulit karena mendapatkan pelatihan yang tepat, namun bagi tingkat pemula hal ini sangat sulit di terapkan karena sering terjadi miss-comunication antar pemain dan pemain sering melakukan multiple block, dan tidak memperhatikan arah badan dan bola dari spiker lawan. Hal ini akan berakibat fatal yakni memberikan poin secara mudah kepada lawan.

Tahapan pemula merupakan tingkatan paling bawah. Pada tahapan ini tidak banyak pemain yang memiliki pengalaman yang cukup dalam suatu pertandingan yang dikarenakan kurangnya jumlah pertandingan yang diikuti. Didasarkan hal ini pemain tingkat pemula lebih menitik beratkan pertahanan kepada pemain belakang. Dengan menanggung resiko apabila bola tidak bisa diantisipasi dengan baik. Dan latihan yang diberikan hanya keterampilan dasar dalam melakukan block dan keterampilan lanjutan akan berkembang secara otodidak yang sebagian besar terjadi dalam pertandingan dan tentunya hal ini akan memberikan resiko kehilangan poin. 
Pelatih di sekolah menengah umumnya hanya terfokus kepada variasi pada pola penyerangan dan sedikit mengabaikan pola dan cara bertahan yang baik dan benar. Hanya sedikit pelatih yang menyadari betapa pentingnya memberikan pelatihan bertahan. Bukannya dengan sengaja pelatih melakukan hal demikian namun pelatih lebih cenderung mengantisipasi serangan lawan yang masih monoton. Tetapi disaat menemukan lawan yang memiliki kemampuan di atas rata-rata maka pemain akan mendapatkan presure dikarenakan pola serangan dapat dipatahkan dengan mudah dan sulit bagi regu untuk mendapatkan poin.

Upaya untuk meningkatkan kemampuan bertahan melalui block dalam permainan, penulis tertarik untuk mengembangkan beberapa pola latihan bertahan, agar saat pertandingan bisa memaksimalkan keterampilan bertahan dan menghasilkan poin dengan lebih efisien.

\section{Keterampilan Block Bolavolí}

Keterampilan adalah kemampuan untuk melaksanakan tugas dengan hasil yang ditentukan dalam jumlah waktu, energi, atau keduanya. Keterampilan kadangkadang dilatih dengan mendefinisikan fokus tugas. Keterampilan terhadap suatu gerak dasar maupun lanjutan dalam kecabangan olahraga tentunya menjadikan suatu keharusan untuk memperoleh hasil yang maksimal. Keterampilan dasar dalam permainan bolavoli itu sangat penting untuk dimiliki oleh atlet dalam mencapai prestasi yang maksimal.

Keterampilan yang dilakukan dengan baik melalui suatu proses yang terencana dan terprogram tentunya akan menghasilkan keterampilan yang maksimal. Tudor O. Bompa (2009) mengatakan:

The learning of new skill set has been suggested to be part process, which may not always be broken into discrete partas because the steps are often blended, during the first part of learning a new skill, the athtlete should receive a detailed explanation of the skill and observ the skill being perform

Bila kemampuan gerak dasar telah dimiliki, maka kelanjutan akan gerak demi mudah diarahkan untuk memiliki keterampilan (skill) yang tinggi dalam kehidupan sehari-hari atau untuk memainkan satu cabang olahraga, Keterampilan pelatih dalam memberikan latihan dapat dilihat dari aspek, yaitu perencanaan latihan, elaksanaan latihan, penilaian dan kesediaan fasilítas/alat. Peningkatan keterampilan (skill) atlet suatu cabang olahraga tentunya didukung dengar aspek-aspek penunjang lainya baik itu program maupun ketersediaan sarana prasarana pendukung lainya.

Keterampilan itu sendiri merupakan koordinasi dan kontrol dari gerakan anggota tubuh yang diarahkan untuk mencapai tujuan tertentu melalui serangkaian kerja otot. John Honeybourne (2006) mengatakan Motor skill is a physical limb movements that are directed towards the achievement of a particular goal. Keterampilan adalah sebagai ukuran kesuksesan dari kualitas gerakan dan menghasilkan gerak konstan yang benar untuk mencapai tujuan tertentu. Tujuan suatu keterampilan akan tercapai tentunya melalui konstribusi otot yang baik pula.

Menurut Widiastuti dalam (Rendy Abrasyi, 2018) Gerak keterampilan adalah gerak yang 
mengikuti pola atau bentuk tertentu yang memerlukan koordinasi dan kontrol sebagian atau seluruh tubuh yang bisa dilakukan melalui proses belajar. Belajar keterampilan gerak melibatkan persoalan yang kompleks, karna tidak hanya menyankut proses yang berkaitan dengan sistem syaraf dan fungsi faal tubuh, namun juga melibatkan aspek fisiologis. Belajar keterampilan gerak merupakan pola gerak tubuh yang bekerja melalui proses sistem saraf sesuai dengan karakteristik atlet.

Keterampilan dalam melakukan suatu gerakan tertentu dapat dilihat dari berbagai dimensi, dari dimensi penggunaan otot, keterampilan dibagi menjadi: (1) keterampilan kasar (gross skill) dan keterampilan halus (fine skill). Dari dimensi stabilitas lingkungan yang dihadapi keterampilan terdiri dari: (1) keterampilan terbuka (open skill) dan (2) keterampilan tertutup (closed skill). Keterampilan tertutup merupakan keterampilan yang dilakukan dalam kondisi yang berubah-ubah namun gerakan yang dilakukan semata-mata karena stimulus dalam diri pelaku sendiri tanpa pengaruh dari luar. Sedangkan keterampilan terbuka merupakan keterampilan yang dipengaruhi oleh kondisi lingkungan yang berubahubah serta sulit untuk diprediksi.

Permainan bolavoli adalah olahraga beregu yang kompleks yang tidak mudah untuk dilakukan oleh setiap orang. Bolavoli merupakan olahraga permainan yang termasuk kedalam keterampilan terbuka, hal ini dapat dilihat dari kecepatan bola dan arah bola yang dimainkan tentunya tidak dapat diprediksi. Tingkat kesulitan sukar atau mudahnya dalam mengolah bola pada permainan bolavoli tergantung dari lingkungan, dimana kemampuan mengolah bola pihak lawan dalam melakukan servis, melakukan serangan dan umpanan serta merubah arah dan kecepatan secara bervariatif tentunya memerlukan teknik yang tinggi dalam permainan bolavoli. Permainan bolavoli dari kajian dimensi penggunaan otot merupaka keterampilan kasar atau gross skil dengan unsur keterampilan melibatkan otot-otot besar untuk menunjang keterampilan gerak.

Keterampilan yang dihasilk

melalui suatu proses pembentukan maupun yang menjadi suatu penghambat dalam terbentuknya keterampilan merupakan studi dalam belajar motorik. Mark L. Latash (2006) mengatakan Motor learning is a complex phenomenon with many components. Depending on the particular task different anatomical structures are involved. Pembelajaran motorik itu sendiri dapat diartikan sebagai fenomena kompleks dengan banyak komponen. Tergantung pada tugas tertentu terhadap struktur anatomi yang dilibatkan.

Belajar motorik adalah studi tentang penguasaan keterampilan motorik, penyempurnaan kinerja keterampilan motorik yang dipelajari atau keahlian keterampilan motorik atau perolehan kembali keterampilan yang sulit atau dilakukan atau tidak dapat dilakukan karena cidera, penyakit atau sejenisnya, perubahan prilaku atau saraf pada seseorang belajar keterampilan motorik dan yang mempengaruhi suatu perubahan.

Proses latihan yang dilakukan untuk meningkatkan kemampuan dan keterampilan tentunya berkaitan erat dengan belajar gerak. Fank Zhu dkk (2012) mengatakan Motor learning has been defined as a set of processes 
associated with practice or experience leading to relatively permanent changes in the capability for responding. Dapat diartikan pembelajaran motorik telah didefinisikan sebagai serangkaian proses yang terkait dengan praktik atau pengalaman yang mengarah ke perubahan yang relatif permanen dalam kemampuan untuk merespons.

Permainan bolavoli adalah permainan beregu yang dimainkan oleh dua tim dan setiap tim terdiri dari enam pemain. Permainan bolavoli merupakan suatu permainan yang komplek yang tidak mudah dilakukan oleh setiap orang. Tujuan pemain dalam bermain adalah menjatuhkan bola secepat mungkin di lapangan lawan lewat atas net dengan bagian badan pinggang ke atas dengan syarat pantulkan bola beraih sempurna sesuai dengan peratur Oleh karena itu permainan bolavoli memerlukan model latihan yang benar dan sesuai agar dalam permainan bolavoli menghasilkan permainan yang sempurna, karena gerakan yang tidak sempurna akan menimbulkan gerakan yang salah dan mengakibatkan permainan tidak berjalan dengan baik. Menurut (Yudasmara 2014) bahwa teknik dasar bolavoli merupakan unsur yang sangat penting dalam permainan bolayoli, tanpa penguasaan teknik dasar yang baik, maka permainan tidak dapat dimainkan dengan sempurna Teknik dasar bolavoli merupakan unsur yang sangat penting dalan permainan bolavoli, tanpa penguasaan teknik dasar yang baik, maka permainan tidak dapat dimainkan dengan sempurna. Teknik dasar bolavoli memiliki peranan yang sangat penting sebelum para pemain meningkatkan kemampuan pada keterampilan yang lebih tinggi.
Dalam permainan bolavoli, teknik block sangat berperan dalam permainan bolavoli dalam upaya mendapatkan kemenangan suatu tim disamping dengan gerakan teknik dasar yang lain.

Block merupakan benteng pertahanan yang utama untuk menangkis serangan dari lawan yang dilakukan di atas net (Ahmadi, 2008) Untuk melakukan block yang baik, pemain harus dapat memperkirakan jatuhnya bola, atau dapat meramalkan kemana kira-kira lawan akan memukul bola. Sedangkan menurut Winarno dan Sugiono (2011) "Bendungan (block) merupakan pertahanan pertama dari serangan lawan". Dari beberapa pendapat diatas dapat disimpulkan bahwa teknik block tersebut dapat dipahami betapa pentingnya teknik block pada permainan bolavoli, latihan teknik yang benar dan sesuai dengan kebutuhan latihan pada block sangatlah penting. Block dapat dilakukan oleh satu, dua atau tiga pemain, yaitu sebagai berikut:

\section{a. Block oleh satu pemain (block tunggal)}

Pada block ini hanya dilakukan tidak lebih dari oleh satu orang pemain, biasanya block yang dilakukan oleh satu pemain sangat lemah dalam mengantisipasi serangan lawan, terlalu banyak celah yang harus ditutupi oleh pemain bertahan. Menurut Winarno \& Sugiono (2011) "Block tunggal adalah melakukan bendungan (block) dari serangan lawan yang dilakukan oleh satu orang pemain". Jika seoarang pemain menguasai teknik block dengan baik dan bisa membaca pergerakan pemain lawan yang akan melakukan serangan maka block ini efektif untuk dilakukan. Tahap-tahap melakukan block tersebut adalah sebagai berikut: 
“(a) melakukan langkah ke kiri atau ke kanan, (b) meloncat ke atas dengan tumpuan kedua kaki, (c) menggerakkan tangan dan lengan ke atas untuk menghalangi lajunya bola dari serangan lawan, (d) mendarat dengan kedua kaki secara lentur" (Winarno \& Sugiono, 2011)

\section{b. Block oleh dua atau tiga pemain (block berkawan)}

Dalam praktik mulai persiapan, pelaksanaan, dan sikap akhir sama seperti block tunggal tetapi perbedaanya terletak pada jumlah pemain yang akan melakukan block. Block ini biasanya paling sering dilakukan karena sangat efekfif untuk membendung serangan dari lawan. Agar hasilnya sempurna maka diperlukan kerjasama yang baik dari masing-masing pemain yang akan melakukan block.

Block adalah serangan balik yang paling efektif dalam permainan bolavoli modern, hal ini disebabkan karena hampir tidak ada jeda antara menyerang dan bertahan Block merupakan teknik dalam permainan bolavoli, keterampilan ini harus dikuasai dengan baik karena dengan melakukan block sebuah regu bisa mendapatkan satu poin bahkan beberapa poin secara berturut-turut.

\section{BAHAN DAN METODE} METODOLOGI

Penelitian pengembangan model block olahraga bolavoli ini menggunakan model penelitian dan pengembangan (Research and Development) dari Borg dan Gall yang terdiri dari sepuluh langkah dalam penelitian yakni antara lain:

(1) Research and information collecting (2) Planning (3) Development of the preliminary from of product (4) Preliminary field testing (5) Main product revision (6) Main field test. (7) Operational product revision . (8) Operational field testing (9) Final produk (10) Dissemination and implementation.

1. Pada penelitian dan pengembangan ini tentunya diharapkan menghasilkan sebuah produk yang dapat digunakan untuk model latihan block bolavoli untuk siswa Sekola Menengah Kejuruan dengan desain model baru atau menyempurnakan yang telah ada secara lengkap sehingga bisa dijadikan sumber belajar lain dalam proses latihan. Untuk mempermudah sistepratika peneliti maka akan digambarkan menggunakan chart mengenai langkah-langkah penelitian pengembangan yang digunakan oleh peneliti berdasa kan langkah-langkah penelitian oleh Borg dan Gall:

2. Research and information collecting (Melakukan penelitian pendahuluan, kajian pustaka, pengamatan, lapangan) untuk mengidentifikasi permasalahan yang dijumpai di lapangan. Planning (melakukan perencanaan berupa identifikasi, definisi keterampilan, perumusan tujuan, penentuan urutan tes, uji ahli, uji coba skala kecil, dan uji coba kelompok besar).

3. Development of the preliminary from of product (mengembangkan jenis/bentuk produk awal meliputi: penyiapan materi penyusunan buku/modul/video dan perangkat evaluasi).

4. Preliminary field testing (melakukan uji coba lapangan tahap awal dari 1-3 sekolah menggunakan 6-10 subjek, pengumpulan data ini menggunakan lembar observasi, lembar kuisioner dan wawancara serta dilanjutkan dengan analisis data). 
5. Main product revision (melakukan revisi produk berdasarkan masukan dan saran-saran dari hasil uji coba lapangan tahap awal)

6. Main field testing (melakukan uji lapangan utama 1-3 sekolah dengan 10-30 subjek)

7. Operational product revision (melakukan revisi terhadap produk operasional, berdasarkan masukan dan saran-saran hasil uji coba lapangan utama).

8. Operational field testing (melakukan uji produk utama dengan subjek sebanyak 10-30 subjek atau 2 sampai 3 sekolah.

9. Final product revision (melakukan revisi terhadap produk akhir, berdasarkan saran dalam uji coba lapangan)

10. Dissemination and implementation (mendesiminasi dan mengimplementasikan melaporkan dan menyebarluaskan produk melalui pertemuan dan jurnal ilmiah, bekerjasama dengan penerbit unuk sosialisasi produk untuk komersial, dan memantau distribusi dan kontrol kualitas

Populasí sebagai obyek yang diteliti pada dasarnya harus mempunyai kualitas dan ciri yang telah ditetapkan baik maupun banyaknya manusia maupun gejala yang ada dalam penelitian ini populasi yang digunakan adalah seluruh siswa bola voli putra pada ekstrakurikuler Sekolah menengah Kejuruan sebanyak 20 orang. Sampel adalah sebagian dari populasi yang

\section{HASIL DAN} PEMBAHASAN

\section{Uji Efektifan Kelompok Eksperimen dan Kontrol}

Data penilaian dari 20 atlet terhadap efektivitas model latihan dianggap mewakili seluruh populasi dengan menggunakan teknik tertentu. Adapun sampel yang diambil dalam penelitian adalah seluruh siswa bola voli putra pada ekstrakurikuler Sekolah menengah Kejuruan sebanyak 20 orang.

Secara umum terdapat 2 variabel dalam suatu penelitian yaitu variable bebas dan variable terikat. Menurut Sugiyono (2010), variable bebas (independen) merupakan variable yang mempengaruhi atau yang menjadi sebab perubahanny atau timbulnya variable terikat (dependen). Sedangkan variable terikat (dependen) merupakan variable yang dipengaruhi oleh variable bebas.Dalam penelitian ini hanya terdapat dua variable yaitu Variabel (independen) adalah "ketrampilan block) dan Variabel (dependen) adalah "siswa sekolah

menengah kejuruan.

Adapun instrument tes dalam penelitian ini adalah sebagai berikut: penelitian ini adalah tes keterampilan block. Pengukuran dilakukan dua kali yaitu tes awal (pretest) dan tes akhir (posttest), tes awal dilakukan sebelum diberikan perlakuan dan tes akhir setelah diberikan perlakuan.

Pelaksanaan tes ini adalah setiap subjek melakukan block bolavoli yang setiap subjek memiliki kesempatan sebanyak 3 kali. Kemudian dari 3 kali percobaan dari setiap block akan di ambil nilai tertinggi. Jika menyentuh net maka tidak dihitung atau skor 0 .

keterampilan block bolavoli dalam kelompok eksperimen dan 20 atlet terhadap efektivitas model latihan keterampilan block bolavoli dalam kelompok kontrol ditunjukkan pada tabel 1: 
Tabel 1. Hasil Pretest dan Posttest Kelompok Eksperimen

\begin{tabular}{|c|c|c|}
\hline Test & Pre-test & Post-test \\
\hline 1 & 9 & 12 \\
\hline 2 & 10 & 13 \\
\hline 3 & 12 & 15 \\
\hline 4 & 11 & 14 \\
\hline 5 & 13 & 16 \\
\hline 6 & 9 & 12 \\
\hline 7 & 11 & 13 \\
\hline 8 & 12 & 15 \\
\hline 9 & 10 & 13 \\
\hline 10 & 12 & 16 \\
\hline 11 & 11 & 14 \\
\hline 12 & 12 & 15 \\
\hline 13 & 9 & 12 \\
\hline 14 & 10 & 13 \\
\hline 15 & 12 & 15 \\
\hline 16 & 13 & 16 \\
\hline 17 & 12 & 15 \\
\hline 18 & 13 & 16 \\
\hline 19 & 11 & 14 \\
\hline 20 & 12 & 15 \\
\hline$\sum$ & 224 & 84 \\
\hline Rata-rata & 11. & 4.2 \\
\hline
\end{tabular}

Sumber: Hasil Keterampilan Block Bolavoli Siswa SMK, 2019.

Tabel 2. Hasil Pretest dan Postest Kelompok Kontrol

\begin{tabular}{ccc} 
Test & Pre-test & Post-test \\
\hline 1 & 10 & 13 \\
\hline 2 & 7 & 10 \\
\hline 3 & 8 & 11 \\
\hline 4 & 10 & 7 \\
\hline 5 & 7 & 9 \\
\hline 6 & 11 & 12 \\
\hline 7 & 10 & 13 \\
\hline 8 & 10 & 12 \\
\hline 9 & 9 & 11 \\
\hline 10 & 9 & 11 \\
\hline 11 & 11 & 13 \\
\hline 12 & 11 & 12 \\
\hline
\end{tabular}

\begin{tabular}{ccc}
\hline 13 & 10 & 13 \\
\hline 14 & 10 & 10 \\
\hline 15 & 9 & 12 \\
\hline 16 & 10 & 10 \\
\hline 17 & 8 & 13 \\
\hline 18 & 11 & 13 \\
\hline 19 & 11 & 10 \\
\hline 20 & 10 & 13 \\
\hline$\sum$ & 188 & 234 \\
\hline Rata-rata & 9.4 & 117 \\
\hline
\end{tabular}

Sumber: Hasil Keterampilan Block Bolavoli Siswa SMK, 2019.

\section{Perhitungan Persentase}

Hasil rekapitulasi keterampilan block bolavoli kelompok eksperimen, bila dibuat dalam bentuk diagram adalah sebagai berikut:

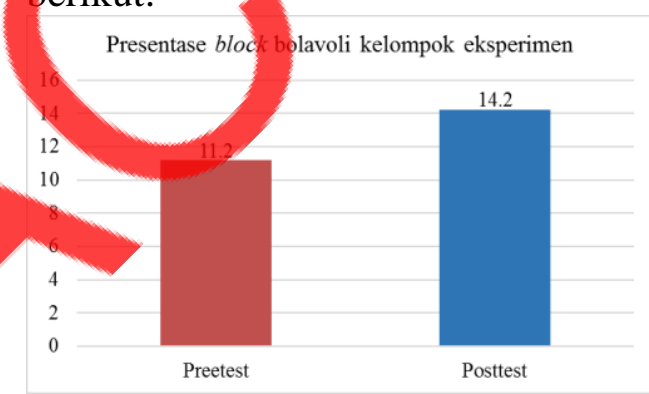

Gambar 1. Diagram Persentase keterampilan block bolavoli kelompok eksperimen

Hasil rekapitulasi keterampilan block bolavoli kelompok kontrol, bila dibuat dalam bentuk diagram adalah sebagai berikut:

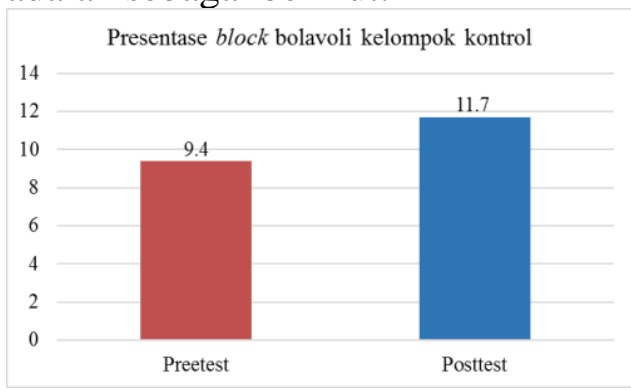

Gambar 2. Diagram Persentase keterampilan block bolavoli kelompok control 
Hasil rekapitulasi signifikasi perbedaan keterampilan block bolavoli kelompok eksperimen dan kelompok kontrol, bila dibuat dalam bentuk diagram adalah sebagai berikut:

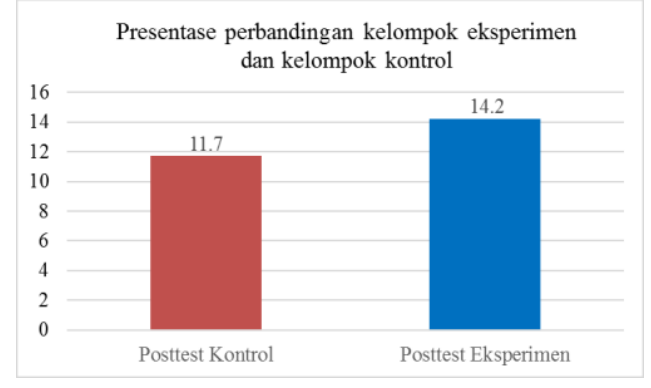

Gambar 3. Diagram presentase perbandingan keterampilan block bolavoli kelompok eksperimen dan kelompok control

Dalam uji signifikan perbedan dengan SPSS 20 didapat hasil thitung $=5,767 \mathrm{df}=38$ dan $\mathrm{p}$-value $=$ $0,00<0,05$ yang berarti terdap perbedaan yang sangat signifikan latihan keterampilan block pada cabang olahraga Bolavoli pada ekstrakulikuler sekolah menengah kejuruan di Kabupaten Pandeglang.

Berdasarkan

tersebut di atas dapat dikatakan bahwa model latihan keterampialn block pada cabang olahraga Bolavoli yang dikembangkan efektif dan meningkatkan kemampuan block pada cabang olahraga bolavoli.

Berdasarkan perolehan data dan pengolahân data maka dapat disimpulkan bahwa model latihan keterampilan block pada cabang olahraga Bolavoli layak untuk digurakan pada kegiatan ekstrakulikuler Bolavoli Sekolah Menengah Kejuruan di Kabupaten Pandeglang.

Berdasarkan pengolahan data dari uji coba kelompok eksperimen melalui tes keterampilan block bolavoli chagi dengan tes awal mendapatkan hasil rata-rata 11,2 kemudian diberikan perlakuan penerapan item-item model latihan yaitu model latihan keterampilan block dengan perlakuan sebanyak 16 kali pertemuan, setelah diberikan perlakuan selama 16 kali pertemuan kemudian peneliti melakukan posttest untuk pengambilan nilai akhir dengan tujuan untuk melihat keefektifan model latihan yang diterapkan. Hasil preetes dan posttest terdapat peningkatan yang signifikan dengan nilai rata-rata 14 , untuk peningkatan keterampilan block.

Perolehan data dari hasil uji cobamakhir yang dilakukan yaitu posttest dari uji kelompok éksperimen dan uji kelompok kontrol, untuk kelompok ekperimen mendapatkan hasil nilai rata-rata 14,2 sedangkan untuk kelompok kontrol mendapatkan hasil nilai ratarata 11,7. Berdasarkan hasil yang didapat yaitu nilai rata-rata antara kelompok eksperimen dan kelompok kontrol, kelompok eksperimen lebih efektif dibandingkan dari kelompok kontrol.

Model latihan Keterampilan block pada cabang olahraga Bolavoli yang sudah dikembangkan oleh penulis tentunya bertujuan untuk meningkatkan Keterampilan block pada cabang olahraga Bolavoli. Produk yang telah dikembangkan oleh penulis memiliki beberapa keunggulan yaitu antara lain:

- Atlet lebih aktif dan senang dalam mengikuti proses latihan.

- Atlet terlihat antusias dan nyaman dalam mengikuti latihan.

- Model latihan keterampilan block bolavoli dibuat berdasarkan karakteristik 
siswa Sekolah Menengah Kejuruan.

Penelitian yang dilakukan oleh peneliti tentunya sudah secara maksimal sesuai dengan kemampuan peneliti. Penelitian ini tentunya masih terdapat kekurangan dan keterbatasan yang harus diakui dan perlu dikemukakan sebagai bahan pertimbangan dalam menganalisis hasil penelitian yang dicapai. Keterbatasan-keterbatasan dalam penelitian ini antara lain sebagai berikut:

Adanya faktor-faktor psikologi yang mempengaruhi hasil penelitian ini yang tidak dapat dikontrol, antara lain : percaya diri, minat, motivasi dan faktor psikologi lainnya.

Faktor-faktor lain yang mempengaruhi hasil penelitian yang tidak dapat dikontrol seperti kondisi fisik atlet yang tidak dalam kondi baik dan stabil.

Keterbatasan waktu dan dana sehingga tidak bisa memaksimalkan penelitian, baik produk yang dihasilkan maupun penerapan produk yang dilakukan.

\section{KESIMPULAN DANSARAN} Simpulan

Berdasarkan data yang diperoleh dari hasil penelitian yang terdiri dari validasi ahli, uji coba kelompok kecil, uji coba kelompok besar serta uji keefektifan maka dapat disimpulkan bahwa:

Pengembangan model latihan keterampilan block bolavoli untuk siswa sekolah menengah kejuruan ini dapat memberikan inovasi guna mempelajari serta melaksanakan latihan block secara efektif dan efisien.

Materi model latihan keterampilan block bolavoli untuk siswa sekolah menengah kejuruan yang telah peneliti kembangkan sebanyak 20 item model, efektif dapat meningkatkan kemampuan keterampilan block dengan cepat dan benar.

\section{Saran}

Agar penelitian ini terealisasikan, maka perlu kiranya penulis ajukan beberapa saran, yaitu:

Bagi Atlet, disarankan terus meningkatkan keterampilan block dalam berbagai aspek itu sendiri sehingga mampu bermaian bolavoli secara optimal dan baik terutamá dalam bertahan

Para pelatih kemajuan olahraga di ekstrakurikuler sekolah menengah kejuruan di Kabupaten Pandeglang supaya terus memberikan yang terbaik pada Atletnya seperti latihan dan dukungan sarana prasarana.

Bagi sekolah untuk terus memberikan dukungan terhadap kegiatan olahraga bagi terutama dalam bidang sarana dan prasarana olahraga itu sendiri.

\section{DAFTAR PUSTAKA}

Achmad, I. Z. (2016). Hubungan Antara Power Tungkai, Koordinasi Mata- Tangan, Dan Rasa Percaya Diri Dengan Hasil Keterampilan Open Spike Bola Voli Irfan. Jurnal Pendidikan UNSIKA], 4(1), 78-90.

Borg. W. R \& Gall, M. D. Educational Research An Introduction. New York : Longman, 1983

Dieter Beutelstahl. Belajar Bermain Bola Volley. Bandung: Pionir jaya. 2015.

Honeybourne, Jhon. Acquiring Skill in Sport. New York: Routledge, 2006 
Nuril Ahmadi. Panduan Olahraga Bolavoli. Surakarta: Era Pustaka Utama. 2008.

Rendy Abrasyi dkk, Model Latihan Passing Bawah Bola Voli Pada Siswa Sekolah Menengah Pertama, Jurnal Sport Area, Vol 3 No 2 2018.

Sugiyono.2010. Metode Penelitian Kualitatif dan Kuantitatif .Bandung: Alfabeta.

Tudor O Bompa, dan G.Gregory Haff. Periodization : theory and methodology of training. Human Kinetics, 2009

Widowati, Arti. Modal Sosial Budaya dan Kondisi Lingkungan Sehat dalam Pembinaan Prestasi Olahraga Pelajar, Jurnal Kesehatan Masyarakat, ISSN $1858-1196$.

Winarno, ME \& Sugiono I. 2011 Sejarah dan Teknik Dasa Permainan Bolavoli. Malang: Fakultas Ilmu Keolahragaan

Yudasmara, D.S. 2014. Pengembangan Model Latihan Teknik Block dalam Bolaoli. Jurnal IPTEK Olahraga Vol. $16 \quad$ (1) Januari-April. Halaman 79101

Uusmar, A. (2017). Upaya Penngkatan Teknik Permainan Bolavoli Melalui Modifikasi Permainan Siswa Kelas X SMA Negeri 2 Kampar. Jurnal PAJAR (Pendidikan dan Pengajaran), (1), 143152.

Zhu, Fank, Jamie Poolton And Rich Masters. Neuroscientific Aspects Of Implicit Motor
Learing in Sport. New York

: Routledge, 2012. 